\title{
Studies on Succession and Population Dynamics of Sap Feeders as Influenced by Weather on Sesame
}

\author{
R. Saritha*, A. B. M. Sirisha, S. K. Haseena and V. Sujatha \\ Acharya N. G. Ranga Agricultural University, Andhra Pradesh, India \\ *Corresponding author
}

\begin{tabular}{l} 
K e y w o r d s \\
$\begin{array}{l}\text { Sesame, weather } \\
\text { parameters, pest } \\
\text { incidence, } \\
\text { correlation, } \\
\text { regression analysis }\end{array}$ \\
\hline Article Info \\
$\begin{array}{l}\text { Accepted: } \\
\text { 08 June } 2020 \\
\text { Available Online: } \\
\text { 10 July } 2020\end{array}$ \\
\hline
\end{tabular}

Population dynamics of sucking pests of sesame viz. thrips, whitefly, leaf hoppers and aphids were studied Correlation between the pest population and weather parameters was analyzed and regression equations were developed. Incidence of aphids, leaf hoppers and thrips on sesame crop during kharif season has started on $25^{\text {th }}$ SMW. Thrips (7.3/ plant) attained peak in the $30^{\text {st }} \mathrm{SMW}$, whereas, whitefly population reached peak during $27^{\text {th }}$ SMW with population of $1.7 /$ plant, whereas, leaf hopper (2.8/plant) and aphid population (12.1/plant) reached the peak in the $31^{\text {st }}$ SMW. Thrips population exhibited significant positive correlation with mean temperature $(\mathrm{r}=0.501)$ and non-significant negative correlation with mean relative humidity $(\mathrm{r}=-0.312)$ and rainfall $(\mathrm{r}=-0.498)$. Whitefly population showed non-significant positive correlation with mean atmosphere temperature $(r=0.285)$ and mean relative humidity $(r=0.028)$ and nonsignificant negative correlative with rainfall $(r=-0.452)$. Leaf hopper exhibited significant positive correlation with mean temperature $(r=0.667)$ while, non-significant negative correlation with mean relative humidity $(r=-0.325)$ and $\operatorname{rainfall}(\mathrm{r}=-0.296)$. Aphid population showed significant positive correlation with mean atmosphere temperature $(r=0.667)$ and non-significant negative correlative with mean relative humidity $(r=-0.236)$ and rainfall $(r=-0.444)$. Incidence of thrips, whitefly, leaf hoppers and aphids on sesame crop during rabi-summer season has started on $3^{\text {rd }}$ SMW. Thrips (3.22/plant), white flies (2.48/plant) leaf hoppers $(10.1 /$ plant $)$ and aphids $(12.8 /$ plant $)$ reached the peak in the $10^{\text {th }}$ SMW. The correlation between weather parameters and sucking pest population followed the pattern similar to kharif season. Regression analysis data of revealed that the multiple non-linear regression equations are sufficient to predict the pest population with prevailing weather parameters.

\section{Introduction}

Sesame (Sesamum indicum L.) is an annual crop belonging to the family Pedaliaceae and is one of the world's oldest oil seed grown for its oil-rich seeds which have diverse uses. Due to the high oil content (38-54 percent), protein (18-25 percent), calcium, phosphorous and oxalic acid (Prasad et al., 2002). India is the world's leading producer of sesame with largest cultivation area. The annual sesame cultivation area in India is about 1.79 mha
(45\% of the world cultivation area) and the total production is 8.02 lakh tones with the productivity of $448 \mathrm{~kg} / \mathrm{ha}$.

Within India sesame is cultivated in the states of Uttar Pradesh, Rajasthan, Madhya Pradesh, Andhra Pradesh, Maharashtra, Gujarat, Tamil Nadu and Orissa and Karnataka. Andhra Pradesh along with West Bengal, Madhya Pradesh, Rajasthan, Uttar Pradesh, Gujarat, and Telangana contributes to more than 85 percent production. 
The acerage of sesame in Andhra Pradesh is 0.61 lakh hectares with production of 0.2 lakh tonnes and productivity of $321 \mathrm{~kg} / \mathrm{ha}$ (Anonymous). The major reasons for low productivity of sesame are its rainfed cultivation in marginal and sub marginal lands and poor management of pests and diseases. Apart from input starved conditions, insect pests are one of the major factor for lower yields, especially sucking pests that harm the crop directly by sap sucking and indirectly by virus and mycoplasma transmission (Ahirwar et al., 2010). Leaf hoppers and white flies act as vectors for incidence of phyllody and leaf curl disease in sesame (Ahirwar et al., 2010).

In designing appropriate management schedules, the awareness of the seasonal occurrence of insect pests at various stages of development would be beneficial to understand the population dynamics of sucking pests. This would in turn provide an insight into the peak cycles which would be helpful in formulating appropriate timely management strategies Hence the present study was contemplated to observe the succession and population dynamics of sap feeders of sesame in relation to various weather parameters under unprotected field conditions.

\section{Materials and Methods}

The experiment was conducted at Agricultural Research Station, Yellamanchili, Visakhapatnam, Andhra Pradesh during rabisummer 2018 and kharif 2018 to investigate the succession and population dynamics of sap feeders on sesame under unprotected field conditions.

\section{Cultivation of sesame}

Untreated sesame seed of variety YLM-66 was sown in the a bulk plot of size 0.2 ha, adopting $30 \mathrm{~cm}$ row to row and $15 \mathrm{~cm}$ plant spacing, during rabi-summer and kharif seasons. All recommended agronomical practices were adopted. The seed rate of 6 $\mathrm{kg} / \mathrm{ha}$ was used and fertilizers applied were FYM @ 10 t/ha and NPK as 40:20:20 with N in two equal splits as basal and at 30 days after sowing (DAS). The kharif crop has been raised as rainfed while three life-saving irrigations have been provided during the rabi-summer. Manual weeding was done twice during each of the season. No plant protection measures were taken up during the entire crop growth period during both the seasons.

\section{Data on population of sucking pests}

Data was recorded in the early hours between 7:00 am and 9:00 am on randomly selected plants in the plot using standard sampling methods Population data for thrips, leaf hoppers, aphids in the sesame crop were recorded at three plant canopy levels (lower, middle and top). Ten plants were selected randomly per spot from five random spots in the plot of 0.2 ha and data on sucking pest population was collected and calculated the mean population. The recorded populations of sap feeders were presented standard weekwise from initial appearance till crop maturity.

\section{Weather data}

Weather data pertaining to maximum and minimum temperature $(\mathrm{C})$; maximum and minimum relative humidity $(\%)$ and rainfall $(\mathrm{mm})$ were collected for the standard weeks from the observatory located at Agricultural Research Station, Yellamanchili.

\section{Statistical analysis}

Using Microsoft Excel software, data on insect species and weather parameters were 
statistically analysed for correlation. The data collected on sucking pests were correlated with the weather parameters following the standard weather week (SMW) [Steel and Torry, 1980].

$$
r_{x y}=\frac{\sum X Y-\sum X \sum Y}{\sqrt{\left[\sum X^{2}-\frac{\sum X^{2}}{n}\right]}-\left[\sum Y^{2}-\frac{\sum Y^{2}}{n}\right]}
$$

Where,

$r_{x y}=$ Simple corelation coefficient

$\mathrm{X}=$ Variable (abiotic component.)

$\mathrm{Y}=$ Variable(No. of Insects per plant)

$\mathrm{n}=$ Number of observations

The correlation coefficient (r) values were subjected to the test of significance using ttest

$t=\frac{r}{\sqrt{1-r^{2}}} X \sqrt{n-2} \sim t_{n-2} d . f$

The calculated t-value obtained was compared with tabulated t-value at $5 \%$ level of significance

\section{Regression analysis}

The data on insect populations and weather parameters was subjected to nonlinear regression analysis was carried out using microsoft excel software and developed the regression equations (Steel and Torry, 1980).

\section{Results and Discussion}

The mean population of aphids, whitefly, leaf hoppers \& thrips and the standard week wise along with weather parameters are presented in Table 1(kharif) and Table 2 (rabi-summer). The findings of the current investigation and the related discussion are outlined hereunder.

\section{Population dynamics of thrips}

The thrips incidence reported during $25^{\text {th }}$ standard meteorological week (SMW) in the kharif season with an average population of 1.10 /plant. The population increased and peaked during $30^{\text {st }}$ SMW with mean population of 7.3 thrips/plant. The population then decreased by the $34^{\text {th }}$ SMW with average population of 2.2 thrips/ plant at the time of maturity as reported in Fig.1. The thrips population exhibited significant positive correlation with minimum temperature $(\mathrm{r}=0.662)$, mean temperature $(\mathrm{r}=0.501)$, relative humidity $(\mathrm{r}=0.809)$ while, nonsignificant positive correlation with maximum temperature $(\mathrm{r}=0.416)$ and negative correlation minimum relative humidity $(\mathrm{r}=-0.468)$, mean relative humidity $(\mathrm{r}=-0.312)$ and rainfall( $\mathrm{r}=-$ $0.497)$ as shown in Table 3.

During rabi-summer season, the thrips population observed on $3^{\text {rd }}$ SMW with an average population of 0.3 thrips/plant and increased till $11^{\text {th }}$ SMW and peaked with 3.22 thrips/plant, thereafter population decreased and finally reported 1.72 thrips on $12^{\text {th }} \mathrm{SMW}$ at crop maturity as shown in Fig.5. The maximum temperature $(r=0.11)$ had positive insignificant correlation with thrips population, whereas significant negative correlation with minimum temperature ($0.576)$, mean relative humidity $(\mathrm{r}=-0.642)$ and non-significant negative correlative with mean temperature $(\mathrm{r}=-0.311)$, maximum relative humidity $(r=-0.206)$. It was indicated that the mean temperature and relative humidity favored the pest population. These results are in accordance with the Ahirwar, et al., 2009.

\section{Population dynamics of whitefly}

The whitefly incidence reported during $27^{\text {th }}$ standard meteorological week (SMW) in the kharif season with an average population of 1.5 /plant. 
The population peaked during $28^{\text {th }} \mathrm{SMW}$ with an average population of 1.7 /plant, then decreased till the $34^{\text {th }}$ SMW with average population of 1.0/plant as reported in Fig.2. Correlation studies carried out between meteorological parameters and whitefly population showed a positive correlation maximum temperature $(\mathrm{r}=0.181)$, minimum temperature $(\mathrm{r}=0.0 .53)$, mean temperature $(\mathrm{r}=0.284)$, minimum relative humidity $(\mathrm{r}=0.029)$ and mean relative humidity $(\mathrm{r}=0.028)$, while with non-significant negative correlation was observed with maximum relative humidity $(\mathrm{r}=-0.018)$ and rainfall $(\mathrm{r}=-$ 0.452).

During rabi-summer season, the whitefly population observed on $3^{\text {rd }}$ SMW with an average population of 0.3 /plant and increased till $12^{\text {th }}$ SMW and peaked with 2.28 whitefly/plant as shown in Fig.5. The maximum temperature $(\mathrm{r}=0.11)$ had positive insignificant correlation with whitefly population, whereas significant negative correlation with minimum temperature (0.733), and non-significant negative correlative with mean temperature $(\mathrm{r}=-0.366)$, maximum relative humidity $(\mathrm{r}=-0.437)$, minimum relative humidity $(-0.074)$ and mean relative humidity $(-0.174))$. It was indicated that the Maximum temperature and rainfall were significantly positively correlated with the population of pest whereas the minimum temperature and relative humidity were showed significant negative correlation. Similar results reported by Bondre et al., 2016; Ba Angood et al., 2000 and Ahirwar et al., 2009.

\section{Population dynamics of leaf hoppers}

Incidence of leaf hoppers during kharif season reported during $25^{\text {th }}$ standard meteorological week (SMW) with an average population of 0.9 /plant. The population steadily increased and peaked during $31^{\text {st }}$ SMW with an average population was $2.8 /$ plant, the mean temperature and relative humidity of $30.8{ }^{\circ} \mathrm{C}$ and $70 \%$, respectively observed during the week. Later, the population then decreased till the $34^{\text {th }}$ SMW with average population of 2.1 leaf hopper/plant as shown in Fig.3. The leaf hopper population exhibited significant positive correlation with mean temperature ( $\mathrm{r}$ $=0.667$ ) while, non-significant negative correlation with mean relative humidity $(\mathrm{r}=$ 0.325) and rainfall ( $\mathrm{r}=-0.296)$. Leaf hopper population shown positive correlation with maximum relative humidity $(\mathrm{r}=0.866)$ and negative with minimum relative humidity $(\mathrm{r}=$ -0.493).

Similar trend was also observed during rabisummer season; the leaf hopper population observed on $3^{\text {rd }}$ SMW with an average population of 2.0/ plant and steadily increased till $11^{\text {th }}$ SMW and peaked with $10.4 /$ plant and at crop maturity the population recorded was 9.6/plant on $12^{\text {th }}$ SME as shown in Fig.6.

The mean temperature $(\mathrm{r}=0.016)$, maximum temperature $(\mathrm{r}=0.435)$ and mean relative humidity $(r=0.267)$ had positive insignificant correlation with leaf hopper population and shown non-significant negative correlative with maximum relative humidity $(\mathrm{r}=-0.397)$ and minimum temperature ( $\mathrm{r}=-0.331)$. Shukla et al., 2014; Mishra et al., 2015 have also reported similar trends in population dynamics of leaf hoppers in sesame.

\section{Population dynamics of aphids}

Incidence of aphids during kharif season was 5.0/plant on $28^{\text {th }}$ standard meteorological week (SMW). The population later increased and peaked during $31^{\text {st }}$ SMW with an average population of $10.8 /$ plant. The population then decreased till the $33^{\text {rd }}$ SMW with average population of 3.5 aphids/plant and finally reported 6.6 aphids/plant on $34^{\text {th }}$ SMW depicted in Fig.4. 
Table.1 Succession and population dynamics of sap feeders as influenced by weather on Sesame (kharif)

\begin{tabular}{|c|c|c|c|c|c|c|c|c|c|c|c|}
\hline \multirow[t]{2}{*}{$\begin{array}{l}\text { Std. } \\
\text { Week }\end{array}$} & \multicolumn{4}{|c|}{$\begin{array}{c}\text { Pests Observed } \\
\text { (population per plant) }\end{array}$} & \multicolumn{7}{|c|}{ Weather parameters } \\
\hline & Thrips & $\begin{array}{l}\text { White } \\
\text { flies }\end{array}$ & $\begin{array}{c}\text { Leaf } \\
\text { hoppers }\end{array}$ & Aphids & $\begin{array}{l}\text { Max. } \\
\text { Temp. } \\
\text { (0 C) }\end{array}$ & $\begin{array}{l}\text { Min. } \\
\text { Temp. } \\
\text { (0 C) }\end{array}$ & $\begin{array}{l}\text { Mean } \\
\text { Temp. } \\
\text { (0 C) }\end{array}$ & $\begin{array}{l}\text { RH } \\
\text { Max } \\
(\%)\end{array}$ & $\begin{array}{l}\text { RH } \\
\text { Min } \\
(\%)\end{array}$ & $\begin{array}{c}\text { Mean } \\
\text { RH } \\
(\%)\end{array}$ & $\begin{array}{c}\text { Rainfall } \\
(\mathbf{m m})\end{array}$ \\
\hline 25 & 1.1 & 0.0 & 0.9 & 0.0 & 31.1 & 24.2 & 27.7 & 86 & 66 & 76 & 17.4 \\
\hline 26 & 1.0 & 0.0 & 0.5 & 0.0 & 32.7 & 24.8 & 28.8 & 87 & 64 & 76 & 54.3 \\
\hline 27 & 0.6 & 1.5 & 0.7 & 0.0 & 33.2 & 25.3 & 29.3 & 85 & 64 & 75 & 29.9 \\
\hline 28 & 1.9 & 1.7 & 1.0 & 5.0 & 31.2 & 25.1 & 28.2 & 87 & 73 & 80 & 5.0 \\
\hline 29 & 5.2 & 0.7 & 1.6 & 3.8 & 31.9 & 25.3 & 28.6 & 88 & 68 & 78 & 20.4 \\
\hline 30 & 7.3 & 0.6 & 2.2 & 3.7 & 33.8 & 25.6 & 29.7 & 90 & 60 & 75 & 11.7 \\
\hline 31 & 4.6 & 1.0 & 2.8 & 10.8 & 35.6 & 26.0 & 30.8 & 91 & 49 & 70 & 10.4 \\
\hline 32 & 2.3 & 0.8 & 1.6 & 7.5 & 33.8 & 25.1 & 29.5 & 88 & 68 & 78 & 16.7 \\
\hline 33 & 1.1 & 0.0 & 3.2 & 3.5 & 31.6 & 24.5 & 28.1 & 87 & 75 & 81 & 62.9 \\
\hline
\end{tabular}

Table. 2 Succession and population dynamics of sap feeders as influenced by weather on Sesame (rabi-summer)

\begin{tabular}{|c|c|c|c|c|c|c|c|c|c|c|}
\hline \multirow{2}{*}{$\begin{array}{l}\text { Std. } \\
\text { Wee } \\
\mathbf{k}\end{array}$} & \multicolumn{4}{|c|}{$\begin{array}{c}\text { Pests Observed } \\
\text { (population per plant) }\end{array}$} & \multicolumn{6}{|c|}{ Weather parameters } \\
\hline & Thrips & $\begin{array}{l}\text { White } \\
\text { flies }\end{array}$ & $\begin{array}{c}\text { Leaf } \\
\text { hopper }\end{array}$ & Aphids & $\begin{array}{l}\text { Max. } \\
\text { Temp. } \\
\left({ }^{0} \mathrm{C}\right)\end{array}$ & $\begin{array}{l}\text { Min. } \\
\text { Temp. } \\
\left({ }^{0} \mathrm{C}\right)\end{array}$ & $\begin{array}{c}\text { Mean } \\
\text { Temp. } \\
\left({ }^{0} \mathrm{C}\right)\end{array}$ & $\begin{array}{c}\text { RH } \\
\text { Max } \\
(\%)\end{array}$ & $\begin{array}{c}\text { RH } \\
\text { Min } \\
(\%)\end{array}$ & $\begin{array}{c}\text { Mean } \\
\text { RH } \\
(\%)\end{array}$ \\
\hline 3 & 0.3 & 0.5 & 2.0 & 3.3 & 33.7 & 17.8 & 25.8 & 93 & 43 & 68 \\
\hline 4 & 0.22 & 0.4 & 3.1 & 2.1 & 33.2 & 17.2 & 25.2 & 90 & 44 & 67 \\
\hline 5 & 2.5 & 0.9 & 4.2 & 4.8 & 34.3 & 17.7 & 26.0 & 92 & 32 & 62 \\
\hline 6 & 1.82 & 0.7 & 1.26 & 5.48 & 31.7 & 16.2 & 24.0 & 90 & 39 & 65 \\
\hline 7 & 1.7 & 0.88 & 1.14 & 3.3 & 31 & 15.4 & 23.2 & 88 & 36 & 62 \\
\hline 8 & 2.04 & 1.2 & 1.4 & 9.26 & 31.6 & 14.3 & 23.0 & 90 & 27 & 59 \\
\hline 9 & 2.98 & 1.86 & 2.1 & 11.54 & 33 & 15.7 & 24.4 & 91 & 28 & 60 \\
\hline 10 & 3.12 & 2.22 & 3.92 & 12.8 & 33.5 & 14.8 & 24.2 & 90 & 38 & 64 \\
\hline 11 & 3.22 & 2.48 & 10.1 & 9.42 & 33.6 & 14.7 & 24.2 & 89 & 34 & 62 \\
\hline 12 & 1.72 & 2.28 & 9.6 & 8.62 & 32.8 & 14.8 & 23.8 & 88 & 50 & 69 \\
\hline
\end{tabular}


Table.3 Correlation coefficient of sap feeders of sesame with respect to weather parameters

\begin{tabular}{|l|c|c|c|c|}
\hline \multicolumn{1}{|c|}{ Parameter } & Thrips & Whitefly & Leaf hoppers & Aphids \\
\hline Kharif & & & & \\
\hline Temperature( Max) & 0.416 & 0.181 & 0.646 & 0.639 \\
\hline Temperature( Min) & 0.662 & 0.530 & 0.624 & 0.642 \\
\hline Temperature(Mean) & 0.501 & 0.285 & 0.667 & 0.667 \\
\hline $\begin{array}{l}\text { Relative Humidity( } \\
\text { Max) }\end{array}$ & 0.809 & -0.018 & 0.866 & 0.768 \\
\hline Relative Humidity(Min) & -0.468 & 0.029 & -0.493 & -0.392 \\
\hline $\begin{array}{l}\text { Relative } \\
\text { Humidity(Mean) }\end{array}$ & -0.312 & 0.028 & -0.325 & -0.236 \\
\hline Rain fall & -0.498 & -0.452 & -0.296 & -0.444 \\
\hline Rabi-summer & & & & \\
\hline Temperature( Max) & 0.114 & 0.202 & 0.436 & 0.448 \\
\hline Temperature(Min) & -0.577 & -0.733 & -0.331 & 0.459 \\
\hline Temperature(Mean) & -0.311 & -0.366 & 0.017 & 0.451 \\
\hline $\begin{array}{l}\text { Relative Humidity( } \\
\text { Max) }\end{array}$ & -0.206 & -0.438 & -0.398 & -0.173 \\
\hline Relative Humidity(Min) & -0.583 & -0.074 & 0.349 & -0.362 \\
\hline $\begin{array}{l}\text { Relative } \\
\text { Humidity(Mean) }\end{array}$ & -0.643 & -0.174 & 0.267 & -0.410 \\
\hline
\end{tabular}

Table.4 Regression analysis of sap feeders of sesame with respect to weather parameters

\begin{tabular}{|c|c|c|}
\hline Pest & Regression equation & $\begin{array}{l}\text { Regression } \\
\text { coefficient }\end{array}$ \\
\hline \multicolumn{3}{|l|}{ Kharif } \\
\hline Thrips & $\begin{array}{l}\mathrm{X}_{\mathrm{k}}=-103.7-0.98\left(\mathrm{~T}_{\max }\right)+2.13\left(\mathrm{~T}_{\min }\right)+1.0\left(\mathrm{RH}_{\max }\right)-0.004\left(\mathrm{RH}_{\min }\right)+ \\
0.007 \text { (Rain) }\end{array}$ & $\mathrm{R}^{2}=0.79$ \\
\hline White fly & $\begin{array}{l}\mathrm{X}_{\mathrm{k}}=-17.16+0.06\left(\mathrm{~T}_{\max }\right)+1.12\left(\mathrm{~T}_{\min }\right)-0.2\left(\mathrm{RH}_{\max }\right)+0.005\left(\mathrm{RH}_{\min }\right)- \\
0.009 \text { (Rain) }\end{array}$ & $\mathrm{R}^{2}=0.81$ \\
\hline $\begin{array}{l}\text { Leaf } \\
\text { hopper }\end{array}$ & $\begin{array}{l}Y_{k}=-35.7+0.19\left(T_{\max }\right)-0.11\left(T_{\min }\right)+0.36\left(R_{\max }\right)-0.03\left(\mathrm{RH}_{\min }\right)- \\
0.001(\text { Rain })\end{array}$ & $\mathrm{R}^{2}=0.79$ \\
\hline Aphids & $\begin{array}{l}\mathrm{Z}_{\mathrm{k}}=-173.2+1.94\left(\mathrm{~T}_{\max }\right)-0.79\left(\mathrm{~T}_{\min }\right) \\
+1.28\left(\mathrm{RH}_{\max }\right)+0.34\left(\mathrm{RH}_{\min }\right)+0.06(\text { Rain })\end{array}$ & $\mathrm{R}^{2}=0.78$ \\
\hline \multicolumn{3}{|c|}{ Rabi-summer } \\
\hline Thrips & $\mathrm{Xr}=12.4 .+0.59\left(\mathrm{~T}_{\max }\right)-0.38\left(\mathrm{~T}_{\min }\right)-0.22\left(\mathrm{RH}_{\max }\right)-0.09\left(\mathrm{RH}_{\min .}\right)$ & $\mathrm{R}^{2}=0.77$ \\
\hline Whitefly & $\mathrm{Xr}=0.042+0.53\left(\mathrm{~T}_{\max }\right)-0.57\left(\mathrm{~T}_{\min }\right)-0.08\left(\mathrm{RH}_{\max }\right)-0.0009\left(\mathrm{RH}_{\min } \cdot\right)$ & $\mathrm{R}^{2}=0.9$ \\
\hline $\begin{array}{l}\text { Leaf } \\
\text { hopper }\end{array}$ & $\mathrm{Yr}=45.5+2.91\left(\mathrm{~T}_{\max }\right)-0.74\left(\mathrm{~T}_{\min }\right)-1.41\left(\mathrm{RH}_{\max }\right)+0.07\left(\mathrm{RH}_{\min }\right)$ & $\mathrm{R}^{2}=0.82$ \\
\hline Aphids & $\mathrm{Zr}=-86.9+1.38\left(\mathrm{~T}_{\max }\right)-3.58\left(\mathrm{~T}_{\min }\right)+1.18\left(\mathrm{RH}_{\max }\right)-0.017\left(\mathrm{RH}_{\min }\right)$ & $\mathrm{R}^{2}=0.86$ \\
\hline
\end{tabular}




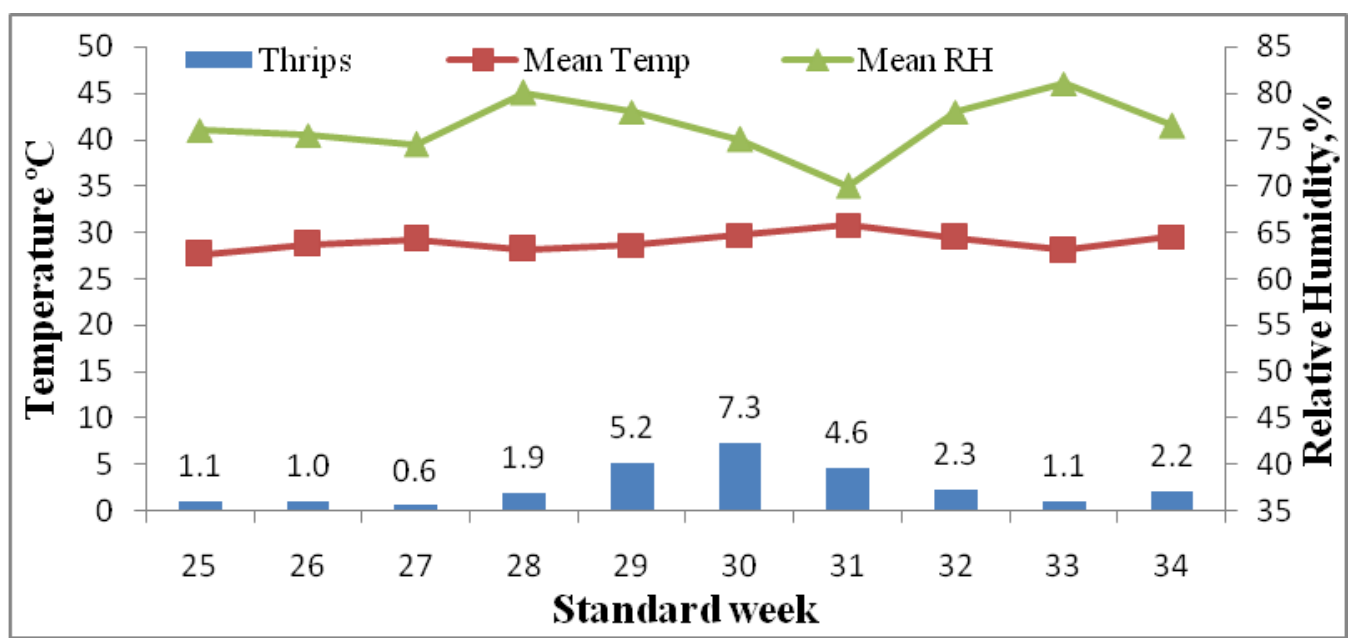

Fig.1 Influence of weather parameters on thrips population during kharif in sesame

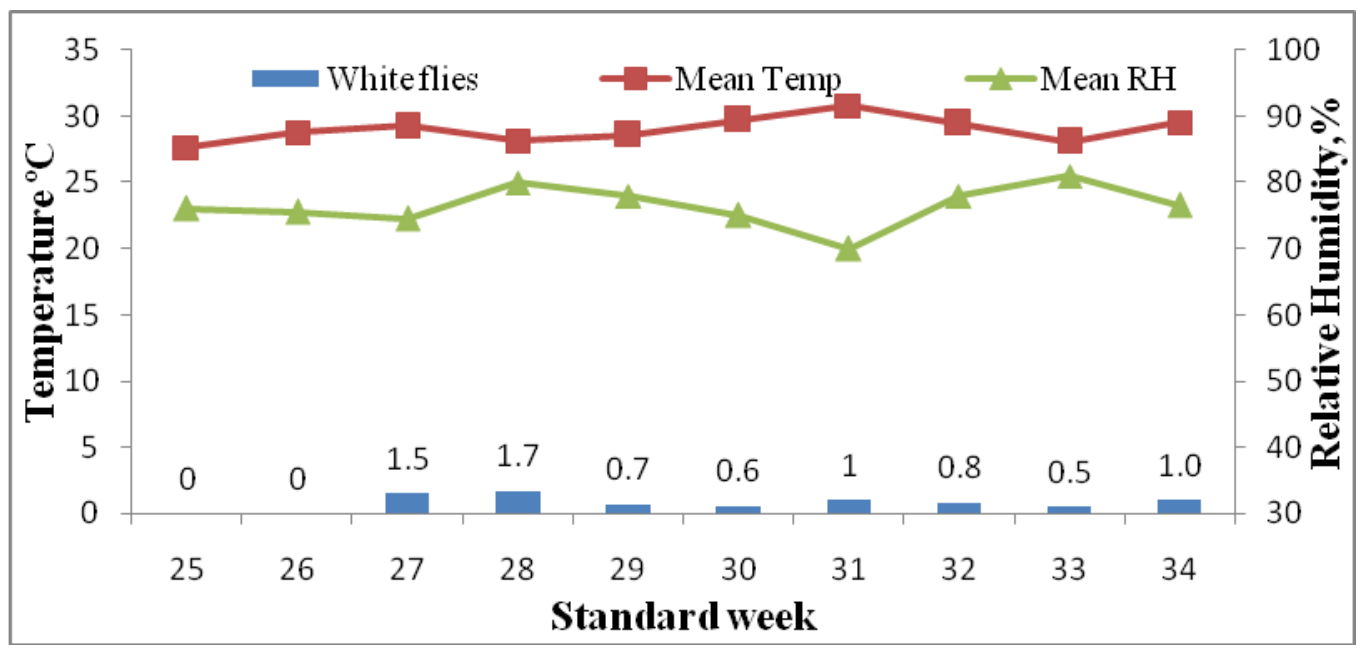

Fig.2 Influence of weather parameters on whitefly population during kharif in sesame

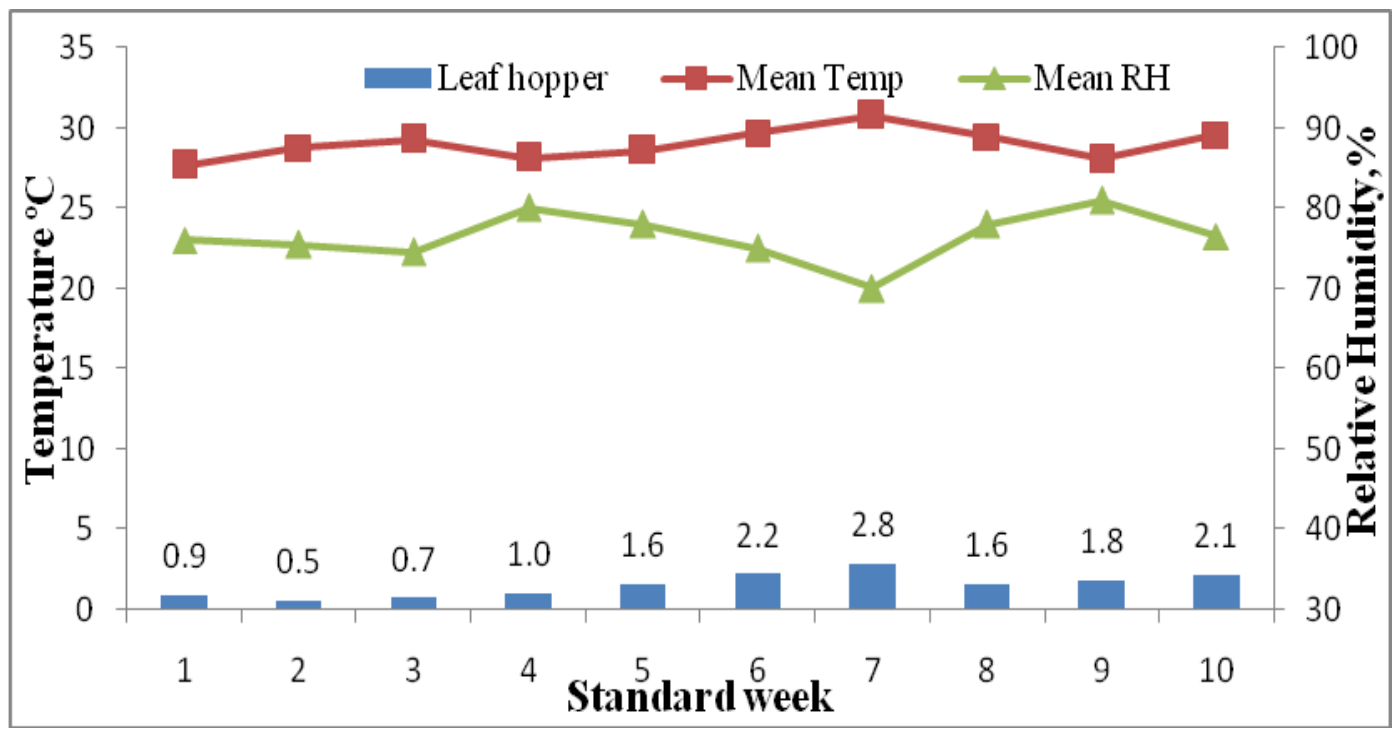

Fig.3 Influence of weather parameters on leaf hoppers population during kharif in sesame 


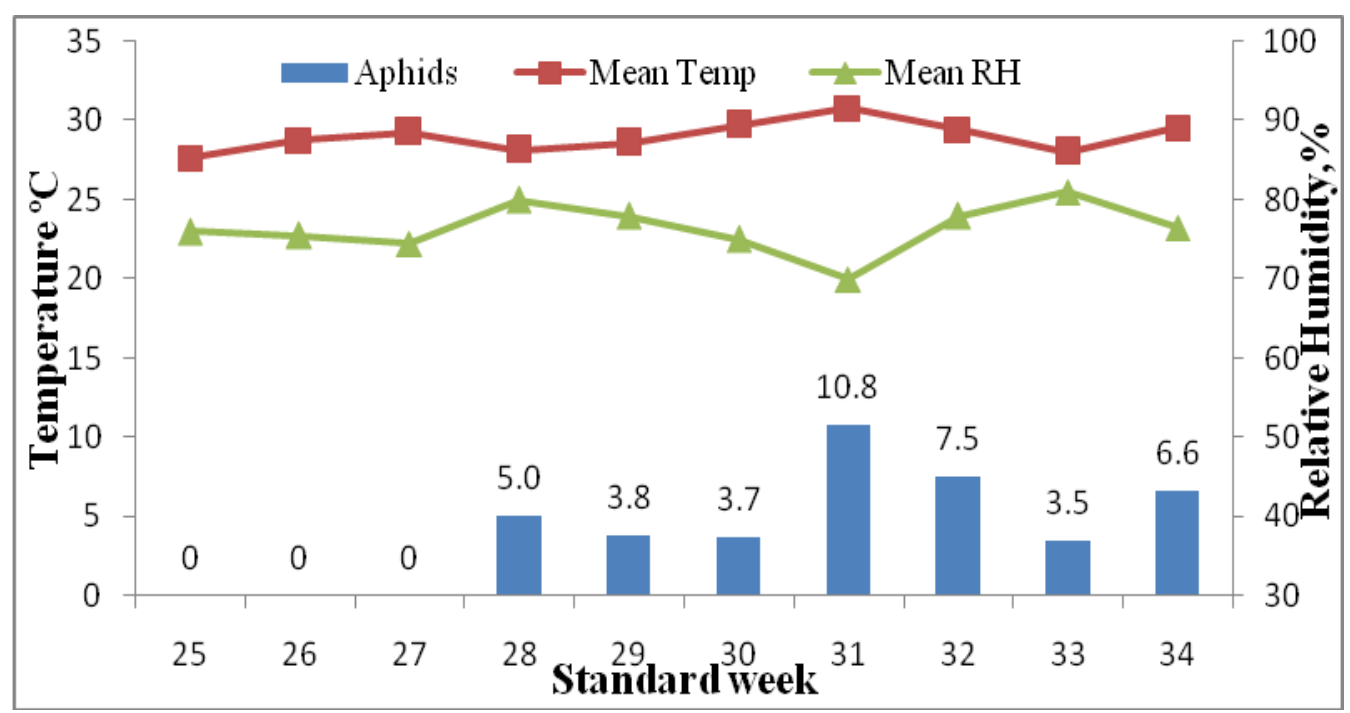

Fig.4 Influence of weather parameters on aphids population during kharif in sesame

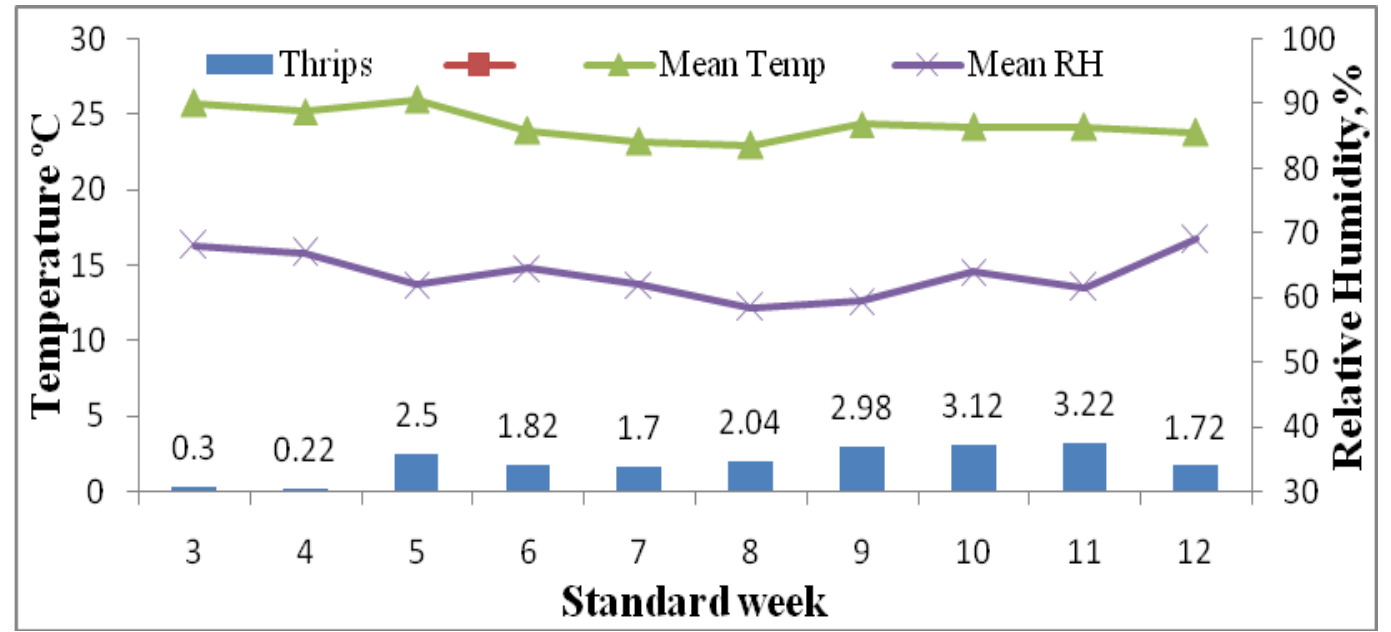

Fig.5 Influence of weather parameters on thrips population during rabi-summer in sesame

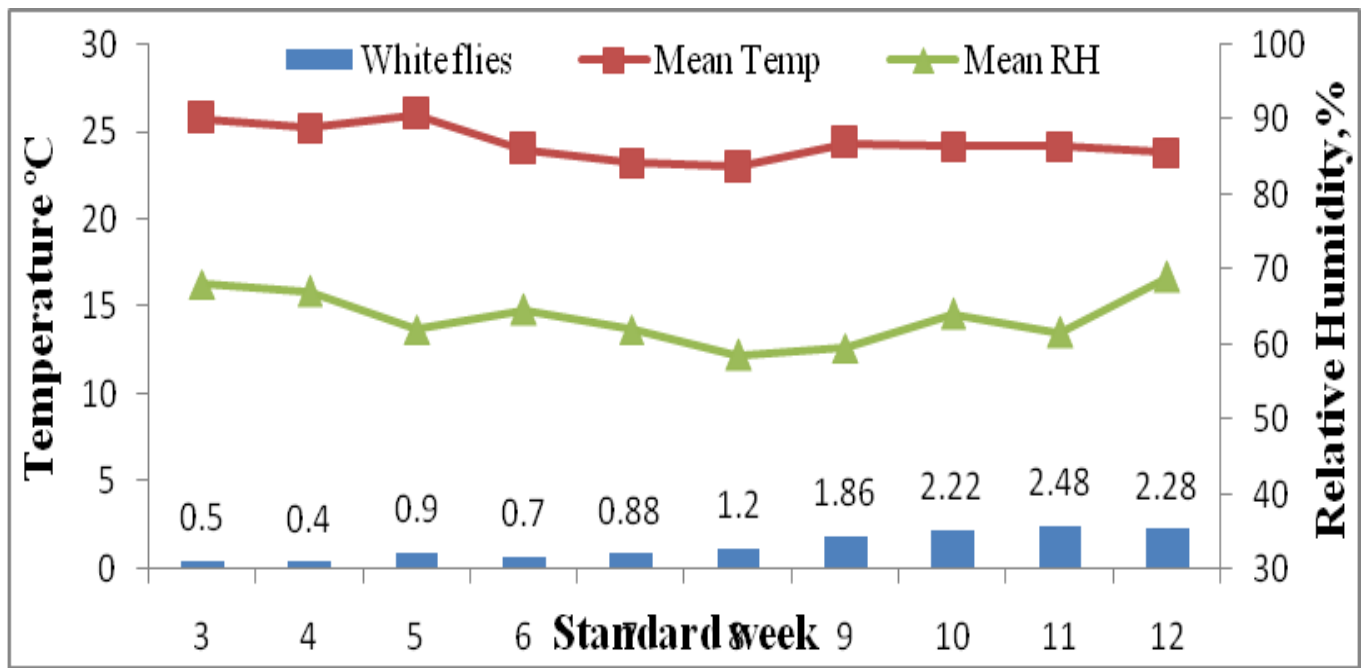

Fig.6 Influence of weather parameters on whitefly population during rabi-summer in sesame 


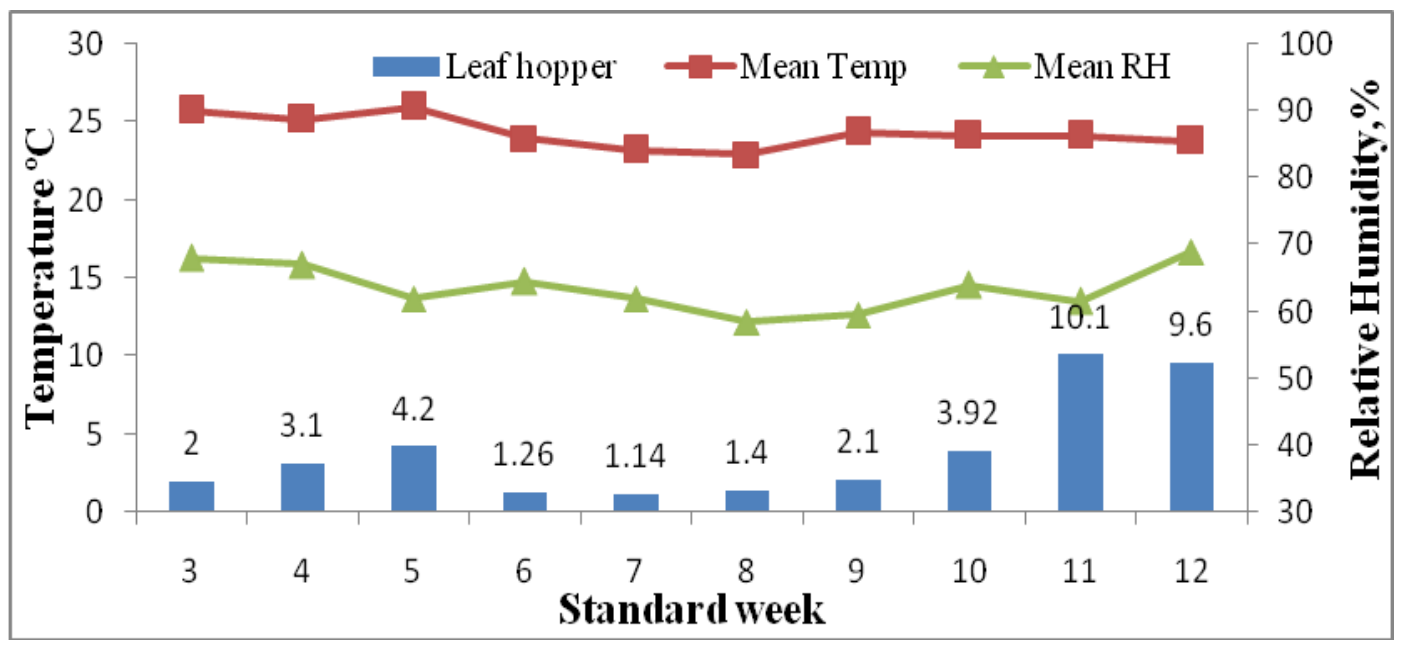

Fig.7 Influence of weather parameters on leaf hopper population during rabi-summer in sesame

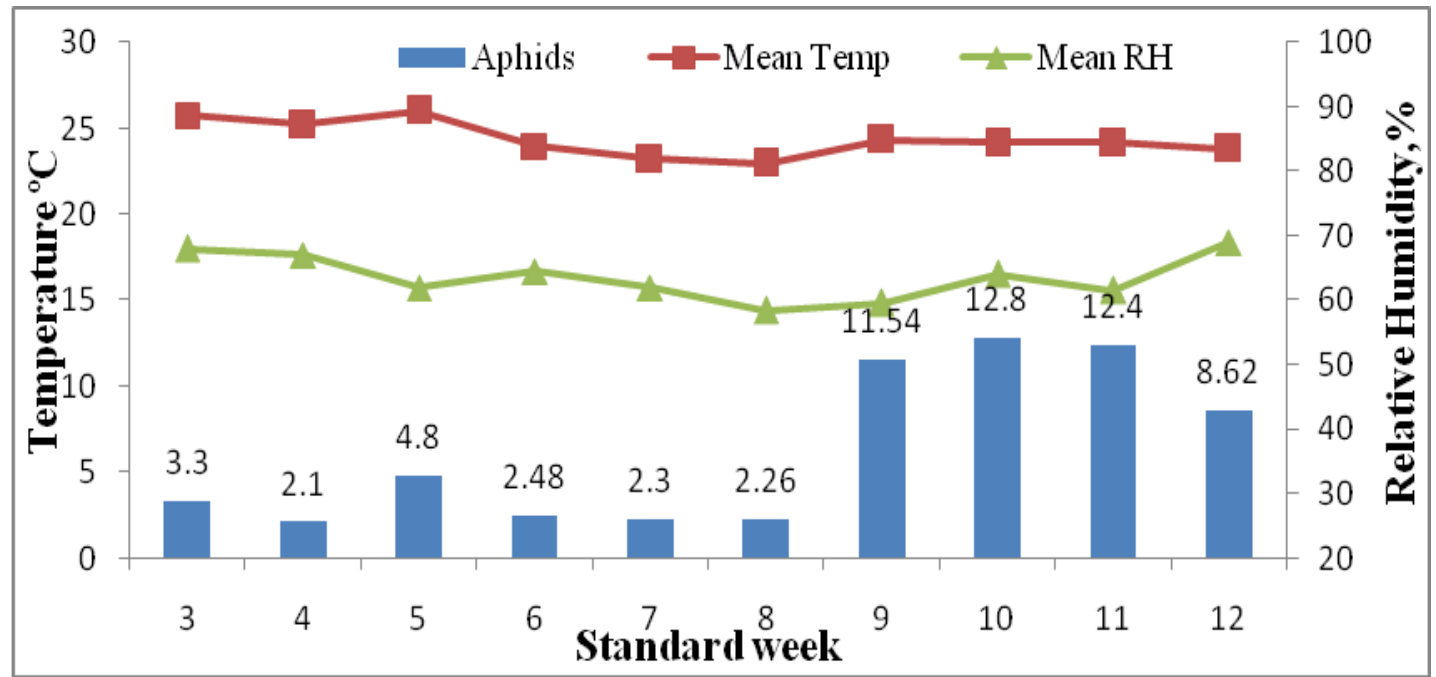

Fig.8 Influence of weather parameters on aphids population during rabi-summer in sesame

The mean temperature varied between 27.7$30.8{ }^{\circ} \mathrm{C}$, while the maximum temperature varied in the wide range $\left(31.1-33.8{ }^{\circ} \mathrm{C}\right)$ and minimum temperature in the narrow range $\left(24.2-26^{\circ} \mathrm{C}\right)$ with positive correlation with aphid population as shown in Table $1 \& 3$.

The mean relative humidity ranged between $70-81 \%$, while the minimum relative humidity varied in the wide range $(49-75 \%)$ and maximum relative humidity in the narrow range (85-91\%) with negative correlation with aphid population as shown in the Table $1 \& 3$. Aphid population showed significant positive correlation with mean atmosphere temperature $(\mathrm{r}=0.667)$ and Non significant negative correlative with mean relative humidity $(r=-0.236)$ and $\operatorname{rainfall}(\mathrm{r}=-0.444)$.

During rabi-summer season the aphid population initially observed on $3^{\text {rd }}$ SMW, thereafter the population spiked with 12.8 aphids/plant on $10^{\text {th }}$ SMW (Fig.4). The mean temperature varied between $23-26{ }^{\circ} \mathrm{C}$, while the maximum temperature varied in the range of $31-33.7{ }^{\circ} \mathrm{C}$ and minimum temperature in the narrow range (14.3-17.8 $\left.{ }^{\circ} \mathrm{C}\right)$. Aphid population shown positive correlation with mean atmosphere temperature $(r=0.451)$ and Non-significant negative correlative with 
mean relative humidity $(\mathrm{r}=-0.14)$. It has been confirmed that the temperature favored to building up the pest population and relative humidity and rainfall constrained the aphid population as depicted in Table 2. The findings are in consensus with Kumar et al., 2010 .

\section{Regression analysis}

The multiple nonlinear regression equation fitted with weather factors during for prediction of aphids, leaf hopper and thrips population and presented in the Table 4 . The regression equation for estimation of thrips population during kharif season is $\left(\mathrm{T}_{\mathrm{k}}\right)=$ $103.7-0.98\left(\mathrm{~T}_{\max }\right)+2.13\left(\mathrm{~T}_{\min }\right)+1.0\left(\mathrm{RH}_{\max }\right)-$ $0.004\left(\mathrm{RH}_{\min }\right)+0.007$ (Rain) $\quad\left(\mathrm{R}^{2}=0.79\right)$, for white fly $\mathrm{W}_{\mathrm{k}}=-17.16+0.06\left(\mathrm{~T}_{\max }\right)+1.12\left(\mathrm{~T}_{\min }\right)$ $0.2\left(\mathrm{RH}_{\max }\right)+0.005\left(\mathrm{RH}_{\min }\right)-$ 0.009 (Rain) $\left(R^{2}=0.81\right)$, for leaf hoppers $L_{k}=-$ $35.7+0.19\left(\mathrm{~T}_{\max }\right)-0.11\left(\mathrm{~T}_{\min }\right)+0.36\left(\mathrm{RH}_{\max }\right)-$ $0.03\left(\mathrm{RH}_{\min }\right)-0.001$ (Rain) $\left(\mathrm{R}^{2}=0.79\right)$ and for aphids $\quad\left(\mathrm{A}_{\mathrm{k}}=-173.2+1.94\left(\mathrm{~T}_{\max }\right) \quad-0.79\left(\mathrm{~T}_{\min }\right)\right.$ $+1.28\left(\mathrm{RH}_{\max }\right)+0.34\left(\mathrm{RH}_{\min }\right)+0.06($ Rain $)$ with $\mathrm{R}^{2}$ of 0.78 .

Similarly the nonlinear regression equation for estimation of pest population for rabisummer season has been developed. The equation for prediction of thrips population is given as $\left(\mathrm{Tr}=12.4 .+0.59\left(\mathrm{~T}_{\max }\right)-0.38\left(\mathrm{~T}_{\min }\right) \quad\right.$ $0.22\left(\mathrm{RH}_{\max }\right)-0.09\left(\mathrm{RH}_{\min }.\right) \quad\left(\mathrm{R}^{2}=0.77\right)$, for white fly $\mathrm{Tr}=12.4 .+0.59\left(\mathrm{~T}_{\max }\right)-0.38\left(\mathrm{~T}_{\min }\right)$ $0.22\left(\mathrm{RH}_{\max }\right)-0.09\left(\mathrm{RH}_{\min } \cdot\right)\left(\mathrm{R}^{2}=0.9\right)$ for leaf hoppers $\mathrm{Lr}=45.5+2.91\left(\mathrm{~T}_{\max }\right)-0.74\left(\mathrm{~T}_{\min }\right)-$ $1.41\left(\mathrm{RH}_{\max }\right)+0.07\left(\mathrm{RH}_{\min }\right)\left(\mathrm{R}^{2}=0.82\right)$ and for aphids $\mathrm{Ar}=-86.9+1.38\left(\mathrm{~T}_{\max }\right)-3.58\left(\mathrm{~T}_{\min }\right)+1.18$ $\left(\mathrm{RH}_{\max }\right)-0.017\left(\mathrm{RH}_{\min }\right)$ with $\mathrm{R}^{2}$ of 0.86 .

These findings regarding relation of weather parameters to incidence of sap feeders were in conformity with the reports of Harish et al., 2015 and Radhika, 2013 for groundnut, Pramod, 2007 for sunflower and Wagh, 2014 in cotton.
The population dynamics of sucking pests on sesame (aphids, whiteflies, leaf hoppers and thrips) were studied and weather parameters were correlated. The study concluded that, the maximum, minimum temperatures and maximum relative humidity have positive correlation with aphids, leafhopper and thrips population and negative correlation with minimum relative humidity and rainfall. The information about the succession and population dynamics of sap feeders in relation to seasonal incidence may be utilized for devising effective management tactics for these pests and achieving higher yields in sesame.

\section{References}

Ahirwar, R.M., S. Banerjee and Gupta, M.P. 2009. Seasonal incidence of Insect pests of Sesame in relation to Abiotic factors. Ann. Pl. Protec. Sci. 17(2): 351-356.

Ahirwar, R.M., M.P. Gupta and Banerjee, S. 2010. Field efficacy of natural and indigenous products on sucking pests of sesame. Indian Journal of Natural Products and Resources. 2:221-226.

Anonymous. 2017. Annual Report of Oilseeds Division, Department of Agriculture, Cooperation \& Farmers' welfare, Krishi Bhawan, New Delhi,.

Ba Angood, S. A., A. M. Ghaleb and Ali, A. M. 2000. Effect of sowing dates on the occurrence of the whitefly Bemisia tabaci and the jassid Jacobiasca lybica on two different local cultivars of sesame in Yemen. Univ. Aden. J. Nat.App. Sci. 4(1) 103-110.

Bondre, C. M., A.K. Pandey and Thomas, M. 2016. Studies on succession and population dynamics of major insect pests of sesame. Progressive Research An International Journal. 11 (VIII): 5249-5251.

Harish, G., M.V. Nataraja, J. Poonam, 
H.Prasanna , S.D. Savaliya and Meera, G.2015. Impact of weather on the occurrence pattern of insect pests on groundnut.

Legume

Research.38(4):524-535.

Kumar, A. Y., A. Hussain, S. K. Khinchi, B.L. Jat and Kumawat, K.C. 2020. Seasonal incidence of sesame leaf and capsule borer, Antigastra catalaunalis (dup.) on sesame in relation to weather parameters. Journal of Entomology and Zoology Studies. 8(1):411-413.

Mishra, M. K., M. P. Gupta, S. R .Thakur, and Raikwar, R. S. 2015. Seasonal incidence of major insect pests of sesame in relation to weather parameters in Bundelkhand zone of Madhya Pradesh. Vol. 17, No. Journal of Agrometeorology. 17(2): 263-264.

Pramod , K. 2007. Sucking pests of sunflower with special reference to thrips palmi karny, its relation with necrosis virus and management. Thesis( Ph.D). College of agriculture, Dharwad, India Prasad, S.S., U.S. Yadav and Srivastava,
R.K.2002. Integrated management studies against olitorius jute pests. Annals of Plant Protection Sciences. 10:248-51.

Radhika, P. 2013. Influence of weather on the seasonal incidence of insect pests on groundnut in the scarce rainfall zone of Andhra Pradesh. Adv. Res. J. Crop Improv. 4 (2): 123-126.

Steel, R.G.D. and Torry, J.H.1980. Principles and procedures of statistics. Publ. Mcgraw Hill Book Company, New York.

Shukla,C. S., P. Deepthi, K.P. Verma and Siva Sankar Reddy, E. 2014. Yield loss assessment and influence of temperature and Relative humidity on charcoal rot development in Sesame (Sesamum indicum L.). J. Life. Sci. 9(1): 193-195.

Wagh, V.M.2014. Correlation between weather parameters and incidence of sucking pests in cotton. M.Sc thesis. Vasantrao Naik Marathwada Krishi Vidyapeeth, Parbhani. India.

\section{How to cite this article:}

Saritha. R., A. B. M. Sirisha, S. K. Haseena and Sujatha. V. 2020. Studies on Succession and Population Dynamics of Sap Feeders as Influenced by Weather on Sesame. Int.J.Curr.Microbiol.App.Sci. 9(07): 839-849. doi: https://doi.org/10.20546/ijcmas.2020.907.097 